\title{
Nitrogen Use and Protein Yield of Two Maize Cultivars in Cohesive Tropical Soil
}

\author{
Georgiana Eurides Carvalho Marques ${ }^{1}$, Alana das Chagas Ferreira Aguiar ${ }^{2}$, Vinicius Ribamar Alencar Macedo ${ }^{3}$, \\ Ester de Paiva Alves ${ }^{3} \&$ Emanoel Gomes Moura ${ }^{3}$ \\ ${ }^{1}$ Federal Institute of Education, Science and Technology of Maranhão, São Luís, Maranhão, Brazil \\ ${ }^{2}$ Federal University of Maranhão, Chapadinha, Maranhão, Brazil \\ ${ }^{3}$ State University of Maranhão, São Luís, Maranhão, Brazil \\ Correspondence: Georgiana Eurides Carvalho Marques, Federal Institute of Education, Science and Technology \\ of Maranhão, 65030-005, São Luís, Maranhão, Brazil. Tel: (5598)-981-946-965. E-mail: geurides@ifma.edu.br
}

Received: December 14, 2016

Accepted: January 17, 2017 Online Published: February 15, 2017

doi:10.5539/jas.v9n3p193

URL: http://dx.doi.org/10.5539/jas.v9n3p193

\begin{abstract}
One major challenge to developing sustainable family farms in tropical regions is increasing nitrogen use efficiency. The aim of this study was to evaluate the combined effects of leguminous residues of low-and high-quality on nitrogen uptake, as well as on content of protein of a Quality Protein Maize (QPM) and of a hybrid maize in a tropical sandy loam soil. The experimental design consisted of randomized blocks with four replicates in a $6 \times 2$ factorial and six treatments: Gliricidia + Clitoria (GC); Gliricidia + Acacia (GA); Leucaena + Gliricidia (LG); Leucaena + Clitoria (LC); Leucaena + Acacia (LA) and a control without legumes (C). A sub-plot was constructed, sowing in each plot two maize cultivars, opened pollination QPM BR 473 and hybrid Ag 7088. We conclude that the combined use of leguminous residues applied on the soil surface might increase the uptake of nitrogen, the protein contents of maize and the grain yield. In bare soil prone to cohesion, the use of synthetic $\mathrm{N}$ is not feasible for both maize yield and for protein yield compared with use of covered soil. The results also showed that the effects of leguminous residue quality on $\mathrm{N}$ uptake may differ from year to year due to variation in water stress days.
\end{abstract}

Keywords: nitrogen uptake, protein yield, maize cultivars, tree legume

\section{Introduction}

For smallholder maize growers in the humid tropics, hybrid seeds and nitrogen $(\mathrm{N})$ fertilizer are very costly (Gaju et al., 2013). Therefore, one major challenge to creating a sustainable and feasible family farm in humid tropical regions is identifying and reducing inefficient use of nitrogen while simultaneously reducing seed cost and intensifying crop production to save conservation areas. Inefficient $\mathrm{N}$ use by crops may also have environmental impacts through nitrate leaching, $\mathrm{N}_{2} \mathrm{O}$ (a greenhouse gas) emissions associated with denitrification by soil bacteria and in $\mathrm{N}$ losses from the root zone. Thus, inefficient use of $\mathrm{N}$ fertilizer is clearly inconsistent with agricultural sustainability and ecological efficiency practices (Hochman et al., 2011).

In contrast, the efficient use of $\mathrm{N}$ by crops results in greater returns in stubble cover, soil organic matter maintenance, higher yields and increased grain protein contents (Silva, Aguiar, Moura, \& Jorge, 2016). For small farmers, particularly in developing countries, the increase in protein grain maize plays an important role because corn is the main staple food and often the sole source of which derive protein and caloric requirements for animal and human nutrition (Ufaz \& Galili, 2008; Mbuya, Nkongolo, \& Kalonji-Mbuya, 2011). Therefore, although product quantity is the principal function that drives the producer revenue stream, product quality is also important for driving economic and social return. However, cereal proteins are of poor nutritional value for monogastric animals (including humans) due to their reduced essential amino acid contents, including lysine, tryptophan and threonine contents (Prasanna, Vasal, Kassahun, \& Singh, 2001). It is in this context that the story of open-pollinated maize cultivars, Quality Protein Maize (QPM), assumes significance, due to its higher levels of lysine and tryptophan than hybrid tropical maize, making it a promising candidate to enrich the human and animal nutrition (Bello et al., 2014). However, adverse environmental effects, such as low N availability, may 
impose severe constraints on exploiting this important alternative crop for family farms. According to Seebauer et al. (2010) to produce higher grain protein contents in maize, a suitable amount of $\mathrm{N}$ must be available.

In sandy loam soils in humid tropical regions, due to poor soil rootability and high rates of nutrient loss by leaching, the low availability and reduced $\mathrm{N}$ use efficiency (NUE) are major factors influencing successful management of agrosystems (Aguiar, Amorim, Coêlho, \& Moura, 2009). Most soils exposed to repeated cycles of wetting and drying tend to undergo hardsetting, due to the generally low free-iron contents and organic carbon levels combined with high fine-sand and silt proportions, which worsens soil rootability and decreases root growth (Daniells, 2012). This process reduces the soil volume accessed by roots, impairs nitrogen uptake, and decreases NUE reducing agrosystem feasibility (Moura et al., 2016). In addition, under tropical meteorological conditions, due to the high atmospheric evaporative demand, the actual transpiration rate may be less than the potential transpiration rate even though soil moisture supply might be considered sufficient. This can lead to loss of turgidity, decreased carbon uptake, cessation of growth and lower productivity of crops (Denmead \& Shaw, 1960).

To calculate the total number of days when soil moisture contents is sufficiently low to cause crop water stress Benjamin, Nielsen, and Vigi (2003) suggested a soil physical indicator symbolized by the expression 'water stress day'. In cohesive sandy loam soil in tropical regions, water stress days can be added from the fourth days without rain or irrigation (Moura et al., 2009).

Thus, to reduce cohesion, increase NUE and the subsequent degradation of structurally fragile tropical soils, some authors have recommended mulching with leguminous residues to provide soil cover (Mulumba \& Lal, 2007; Aguiar et al., 2009). Mulching with surface residues delays soil moisture loss, decreases the evapotranspiration rate, and improves soil rootability (i.e., providing good conditions for root growth) (Qamar et al., 2015). However, this practice will only be successful if a combination of biomass producer species that provide low- and high-quality residues is used. This technique will ensure an adequate release rate of $\mathrm{N}$ during crop growth and maintain soil cover during the entire crop cycle in tropical conditions with high biomass decomposition rates (Moura, Oliveira, Coutinho, Pinheiro, \& Aguiar, 2012).

Thus, we hypothesize, that a combination of different leguminous residues applied on soil surfaces may affect in different ways the uptake of nitrogen of maize cultivars and doing so to alter the protein contents and grain yield. The aim of this study was to evaluate the combined effects of low- and high-quality residues on nitrogen uptake, to compare protein yield of QPM and hybrid maize cultivar in a tropical sandy loam soil prone to cohesion.

\section{Material and Methods}

\subsection{Experimental Site and Trial Set-Up}

The study was carried out in 2014 and 2015 in one experimental field at Maranhão State University, Brazil $\left(2^{\circ} 30^{\prime}\right.$ $\mathrm{S}$ and $\left.44^{\circ} 18^{\prime} \mathrm{W}\right)$. The climate can be described as hot and semi-humid equatorial with two well-defined seasons: a rainy season (January-June) and a dry season with a marked water deficit (July-December). The annual mean rainfall $(\mathrm{mm})$ during the experimental period was $1,457.5 \mathrm{~mm}_{\text {year }}{ }^{-1}$, and the mean minimum and maximum temperatures were $27{ }^{\circ} \mathrm{C}$ and $37{ }^{\circ} \mathrm{C}$, respectively. The climate data were collected in a Remote Automated Weather Station localized on side of experimental area. The water stress days were calculated considering the number of days after four days without rain (Benjamin, Nielsen, \& Vigi, 2003; Moura et al., 2009).

The local soils displayed cohesive characteristics Moura et al. (2012) and were classified as Arenic Hapludults with $260 \mathrm{~g} \mathrm{~kg}^{-1}$ coarse sand, $560 \mathrm{~g} \mathrm{~kg}^{-1}$ fine sand, $80 \mathrm{~g} \mathrm{~kg}^{-1}$ silt and $100 \mathrm{~g} \mathrm{~kg}^{-1}$ clay. Before sowing the experimental area, the chemical properties of soil were determined, as follows: $\mathrm{pH} 5.35$ (in $\mathrm{CaCl}_{2}$ ); $19.29 \mathrm{~g} \mathrm{~kg}^{-1}$ of organic-C; $32.25 \mathrm{mg} \mathrm{dm}^{-3}$ of P; $22.67 \mathrm{mmol}_{\mathrm{c}} \mathrm{dm}^{-3}$ of $(\mathrm{Al}+\mathrm{H}) ; 20.04 \mathrm{mmol}_{\mathrm{c}} \mathrm{dm}^{-3}$ of Ca; $12.79 \mathrm{mmol}_{\mathrm{c}} \mathrm{dm}^{-3}$ of $\mathrm{Mg} ; 1.4 \mathrm{mmol}_{\mathrm{c}} \mathrm{dm}^{-3}$ of $\mathrm{K} ; 56.52 \mathrm{mmol}_{\mathrm{c}} \mathrm{dm}^{-3}$ of CEC; $58.49 \%$ of percentage base saturation.

Four perennial leguminous species were tested, two of which have a higher quality residue, Gliricidia sepium Jacq. (Gliricidia) and Leucaena leucocephala Lam. (Leucena), and two with trees producing a lower quality residue, Clitoria fairchildiana Howard (Clitoria) and Acacia mangium Wild (Acacia) (Aguiar et al., 2010). Leguminous residue quality was determined by amount of nitrogen, lignin and polyphenols in each residue (Tian, Brussaard, \& Kang, 1995). In the alley cropping system, legumes were sown in $4 \mathrm{~m}$ spaces between rows and in $0.5 \mathrm{~m}$ spaces between plants, which resulted in $10 \mathrm{~m} \times 4 \mathrm{~m}$ plots. Since 2003 , maize (Zea mays L.) was grown during the rainy season between the rows of leguminous plants in each plot of $21 \times 4 \mathrm{~m}$ plot with a spacing of 90 $\mathrm{cm}$ between the rows and $33 \mathrm{~cm}$ between the plants.

The alley cropping system included the six treatments: Gliricidia + Clitoria (GC); Gliricidia + Acacia (GA); Leucaena + Gliricidia (LG); Leucaena + Clitoria (LC); Leucaena + Acacia (LA) and a control without legumes 
(C) and four replicates in a randomized block design. A sub-plot was made sowing in each plot two maize cultivars, opened pollination QPM BR 473 and hybrid Ag 7088 grown in the experimental plot between the rows of leguminous plants with a density of five plants per square meter and four rows (Figure 1).

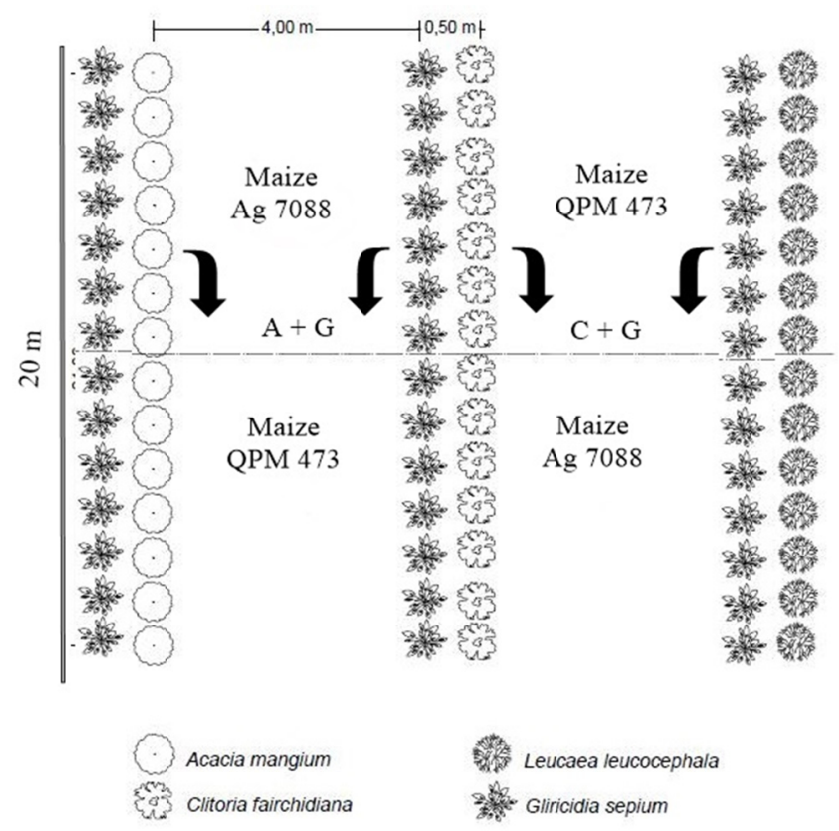

Figure 1. Schematic illustration showing the distribution double rows of legumes and two maize cultivars

The fertilization for maize consisted of applying $120 \mathrm{~kg} \mathrm{ha}^{-1}$ of $\mathrm{P}_{2} \mathrm{O}_{5}$ from triple superphosphate, $5 \mathrm{~kg} \mathrm{ha}^{-1}$ of $\mathrm{Zn}$ in the form of zinc sulphate, $120 \mathrm{~kg} \mathrm{ha}^{-1}$ of $\mathrm{K}_{2} \mathrm{O}$ in the form of potassium chloride and $100 \mathrm{~kg} \mathrm{ha}^{-1}$ of N in the form of urea divided into two applications: one at the time of sowing and another was made at the V6 maize growth stage. The legume plants were pruned every year at a height of $50 \mathrm{~cm}$ from the ground, immediately after corn germination, to maximize sunlight exposure in the cropping area. Biomass of legumes after sowing maize were provided in the following amounts: $4.13 \mathrm{Mg} \mathrm{ha}^{-1}$ for Gliricidia + Acacia and Gliricidia + Clitoria; $3.63 \mathrm{Mg}$ $\mathrm{ha}^{-1}$ Leucaena + Acacia and Leucaena + Clitoria. Combinations of biomass were adjusted according to nitrogen contents and the release curves of the nutrients that were found by Aguiar et al. (2010); Moura et al. (2010) to ensure a uniform contribution of organic $\mathrm{N}$ across the different treatments $\left(100 \mathrm{~kg} \mathrm{ha}^{-1}\right)$.

\subsection{Plant Analyses and Yield Determination}

Plant tissue samples were collected for analyzing $\mathrm{N}$ and the nutrient status the leguminous residues in 2014 and 2015. For maize, 10 plants (equivalent area of $2 \mathrm{~m}^{2}$ ) from each plot were randomly selected at maturity. All of these plant materials were dried at $60{ }^{\circ} \mathrm{C}$ for 3-4 days to obtain a constant weight. $\mathrm{N}$ total was determined using the Kjeldahl method and grain protein was calculated by multiplying the $\mathrm{N}$ content by 6.25 (Association of Official Analytical Chemists, 2005).

Nitrogen accumulation amount was measured on two occasions: at tasseling (NT) (or approximately 1 week before anthesis) and at the physiological maturity stage (total nitrogen accumulated in stems and leaves and amount of nitrogen in grain). The $\mathrm{N}$ accumulation amount and $\mathrm{N}$ remobilization in the plant were calculated following Wang, Guo, Shi, Zhang, and Yu (2015) and N accumulation amount in organs was calculated: [(N concentration from the organ $\mathrm{x}$ dry weight of the organ)]. Based on the measurements of plant dry matter (DM) and $\mathrm{N}$ uptake, we calculated the amount of $\mathrm{N}$ remobilization (NR): [(DM in all vegetative organs at tasseling $\times \mathrm{N}$ concentration at tasseling $)-(\mathrm{DM}$ in all vegetative organs at maturity $\times \mathrm{N}$ concentration in all vegetative organs at maturity)]. The amount of $\mathrm{N}$ uptaken post-tasseling (NPT) was calculated: ( $\mathrm{N}$ accumulation amount in all organs at maturity $-\mathrm{N}$ accumulation amount in all organs tasseling). The contribution of legumes for total $\mathrm{N}$ uptake (CLTN) was calculated following the work of Mon et al. (2016): CLTN = [(TNU in N fertilized plot TNU in Control)/N-fertilized plot], TNU is total $\mathrm{N}$ accumulation in grain and straw. 
We determined the weight of 100 grains by weighing the grain on a scale with an accuracy of $0.0001 \mathrm{~g}$. Grain yield was calculated on the basis of $6 \mathrm{~m}^{2}$ harvest areas in each plot and expressed at $13 \%$ grain moisture content. The protein yield was calculated this way: [(Grain Yield $\times$ Grain Protein) $] / 100$.

\subsection{Statistical Analysis}

The parameters were analyzed using analysis of variance (ANOVA), and means were compared using Duncan's post hoc test at a $* \mathrm{P}<0.05$ significance level. The data were analysed using InfoStat software (InfoStat Group, College of Agricultural Sciences, National University of Córdoba, Argentina).

\section{Results}

All combinations of leguminous residues affected the accumulation of $\mathrm{N}$ until tasseling stage in the two years and in the two maize cultivars. However, there were differences among these treatments in two cultivars in 2014, when the accumulation of $\mathrm{N}$ pre-tasseling was lower in LG than in other treatments with leguminous biomass. In GA and GC it was higher for two cultivars except for LA treatment in the hybrid cultivars. In 2015, accumulation of $\mathrm{N}$ pre-tasseling was higher in LC than in the other treatments in the QPM cultivar except again for LA. There were no differences among the treatments with leguminous to hybrid cultivars, as well as for $\mathrm{N}$ accumulation until tasseling stage (Table 1).

Table 1. Nitrogen at tasseling (NT), amount of nitrogen remobilized (NR) and amount of nitrogen uptake post-tasseling (NPT) in two maize cultivars in the experimental area in 2014 and 2015

\begin{tabular}{|c|c|c|c|c|c|c|}
\hline \multirow{2}{*}{ Treatments } & \multicolumn{2}{|c|}{ NT $\left(\mathrm{kg} \mathrm{ha}^{-1}\right)$} & \multicolumn{2}{|c|}{ NR $\left(\mathrm{kg} \mathrm{ha}^{-1}\right)$} & \multicolumn{2}{|c|}{ NPT $\left(\mathrm{kg} \mathrm{ha}^{-1}\right)$} \\
\hline & 2014 & 2015 & 2014 & 2015 & 2014 & 2015 \\
\hline \multicolumn{7}{|l|}{$Q P M$} \\
\hline $\mathrm{LC}$ & $42.32 \mathrm{~b}$ & $84.44 \mathrm{a}$ & $27.48 \mathrm{~b}$ & $56.75 \mathrm{a}$ & $12.46 \mathrm{~b}$ & $22.46 a b$ \\
\hline LA & $48.23 \mathrm{~b}$ & $71.78 \mathrm{ab}$ & $30.88 \mathrm{~b}$ & $30.75 \mathrm{~b}$ & $23.23 \mathrm{a}$ & $17.61 \mathrm{~b}$ \\
\hline LG & $40.40 \mathrm{c}$ & $51.02 \mathrm{c}$ & $16.19 \mathrm{c}$ & $18.37 \mathrm{c}$ & $13.29 \mathrm{~b}$ & $37.88 \mathrm{a}$ \\
\hline GA & $58.54 \mathrm{a}$ & $65.04 \mathrm{bc}$ & $38.97 \mathrm{a}$ & $22.32 \mathrm{bc}$ & $8.46 \mathrm{bc}$ & $39.36 \mathrm{a}$ \\
\hline $\mathrm{GC}$ & $56.67 \mathrm{a}$ & $66.64 \mathrm{bc}$ & $42.45 \mathrm{a}$ & $29.81 \mathrm{~b}$ & $4.19 \mathrm{c}$ & $30.46 \mathrm{ab}$ \\
\hline $\mathrm{C}$ & $30.60 \mathrm{~d}$ & $47.56 \mathrm{~d}$ & $12.35 \mathrm{c}$ & $17.89 \mathrm{c}$ & $2.86 \mathrm{c}$ & $6.48 \mathrm{c}$ \\
\hline \multicolumn{7}{|l|}{ Hybrid } \\
\hline $\mathrm{LC}$ & $54.81 \mathrm{~b}$ & $78.99 \mathrm{a}$ & $35.54 \mathrm{~b}$ & $40.91 \mathrm{a}$ & $14.14 \mathrm{a}$ & $30.55 \mathrm{c}$ \\
\hline LA & $58.70 \mathrm{ab}$ & $80.09 \mathrm{a}$ & $35.13 \mathrm{~b}$ & $24.27 \mathrm{~b}$ & $18.25 \mathrm{a}$ & $53.65 \mathrm{ab}$ \\
\hline LG & $42.32 \mathrm{c}$ & $80.86 \mathrm{a}$ & $25.61 \mathrm{c}$ & $38.52 \mathrm{a}$ & $16.9 \mathrm{a}$ & $38.89 \mathrm{bc}$ \\
\hline GA & $64.43 \mathrm{a}$ & $89.55 \mathrm{a}$ & $45.16 \mathrm{a}$ & $21.94 \mathrm{bc}$ & $5.99 \mathrm{~b}$ & $42.40 \mathrm{bc}$ \\
\hline $\mathrm{GC}$ & $62.02 \mathrm{a}$ & $80.48 \mathrm{a}$ & $43.09 \mathrm{a}$ & $25.61 \mathrm{~b}$ & $6.97 \mathrm{~b}$ & $60.31 \mathrm{a}$ \\
\hline $\mathrm{C}$ & $39.00 \mathrm{~d}$ & $52.29 \mathrm{~b}$ & $22.21 \mathrm{c}$ & $19.09 \mathrm{c}$ & $5.55 \mathrm{~b}$ & $10.68 \mathrm{~d}$ \\
\hline
\end{tabular}

Note. Different letters in the same column indicate significant differences by Duncan's test $(P<0.05)$. LC $=$ Leucaena and Clitoria; $\mathrm{LA}=$ Leucaena and Acacia; $\mathrm{LG}=$ Leucaena and Gliricidia; $\mathrm{GA}=$ Gliricidia and Acacia; $\mathrm{GC}=$ Gliricidia and Clitoria; $\mathrm{C}=$ control.

The remobilization of nitrogen in 2014 also was higher in GA and GC treatments in the two cultivars. In 2015, the highest remobilization of nitrogen was in LC treatment, but in LG it was also higher than in other hybrid treatments and was not different for the control in the QPM cultivar. Accumulation post-tasseling in 2014 was higher in combinations with leucaena (LC, LA, LG) in the hybrid cultivar, without differences among other treatments. In QPM it was the highest only when leucaena was combined with gliricidia (LG), without differences between control, GA and GC. In 2015, the differences, as for accumulation post-tasseling, were less clear, but the combinations with gliricidia (LG, GA,) were superior to the control and LA in the QPM cultivar. In the hybrid cultivar, it was the highest only when the gliricidia was combined with clitoria (GC). In all the plots with leguminous accumulation, post-tasseling was higher than in the control in 2015.

Mainly for hybrid cultivars, there was wide variation in the contribution of leguminous treatments in the use of $\mathrm{N}$ applied comparing 2014 and 2015. The QPMLC treatment showed lower contribution for total $\mathrm{N}$ uptake than all other treatments in 2014, except for GA. In contrast, in 2015 the highest contribution was provided by the GA treatment (Figure 2a). For hybrid cultivars it was lower in the treatments LC and LG than in LA, GA and GC in 2014. In 2015 a contribution of the legume was higher in GC than LC and LG (Figure 2b). 

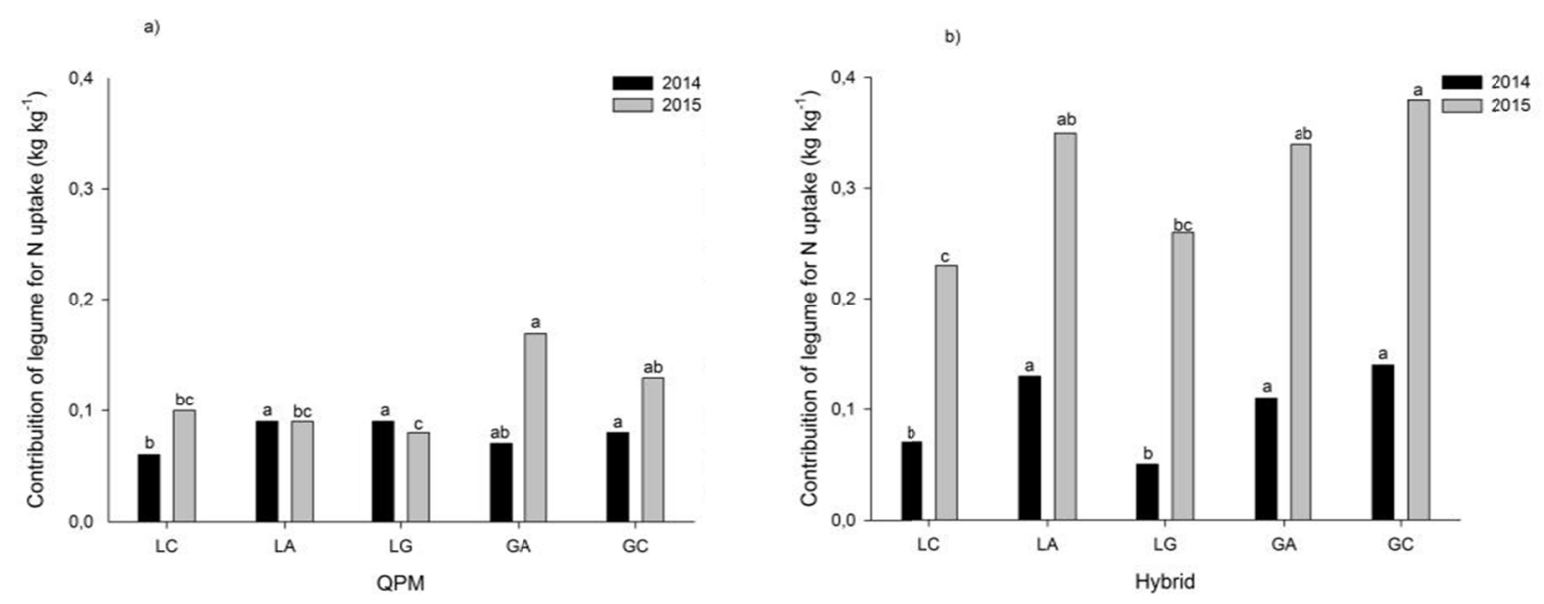

Figure 2. Contribution of legume for total $\mathrm{N}$ uptake (CLTN) in experimental treatments

Note $. \mathrm{LC}=$ Leucaena and Clitoria; $\mathrm{LA}=$ Leucaena and Acacia $\mathrm{LG}=$ Leucaena and Gliricidia; $\mathrm{GA}=$ Gliricidia and Acacia; $\mathrm{GC}=$ Gliricidia and Clitoria; $\mathrm{C}=$ control. a) QPM and b) Hybrid. Different letters above the bars show differences between treatments at the two cultivars at $\mathrm{P} \leq 0.05$ by Duncan's test.

In 2014, combinations with gliricidia increased the grain protein contents in the two cultivars compared to other treatments. The other combinations were not different from the control. In 2015, protein contents were higher in the treatments with clitoria (LC, GC) and the control, in QPM cultivar, without significant difference in the hybrid among the treatments with residues. Protein contents were lower in the LA and LG than in control treatments in QPM cultivars (Figure 3a). In all treatments with leguminous residues, protein contents were higher than in control treatments in the hybrid cultivars, without differences between them (Figure 3b).
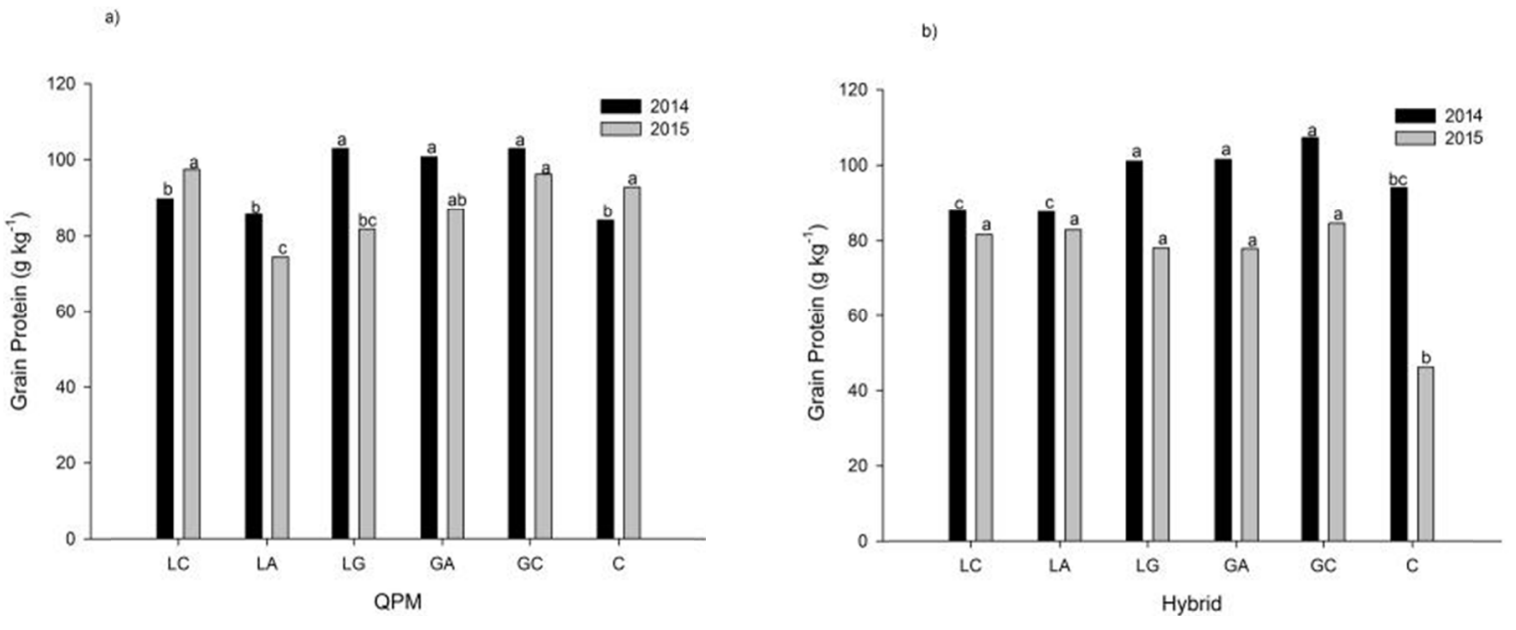

Figure 3. Grain Protein in experimental treatments

Note. $\mathrm{LC}=$ Leucaena and Clitoria; $\mathrm{LA}=$ Leucaena and Acacia; $\mathrm{LG}=$ Leucaena and Gliricidia; $\mathrm{GA}=$ Gliricidia and Acacia; $\mathrm{GC}=$ Gliricidia and Clitoria; $\mathrm{C}=$ control. In a) QPM and b) Hybrid. Different letters above the bars show differences between treatments at the two cultivars at $\mathrm{P} \leq 0.05$ by Duncan's test.

In 2014, total dry matter from two cultivars was higher in LA than in all the other treatments, but it was increased by all combinations of leguminous residues. In 2015, the dry matter production was higher in LG than in the other treatments, except for GC in hybrid and LC and GA in the QPM cultivar. All leguminous residue combinations increased the 1000-grain weight in 2014. In the hybrids, it was higher in LA than in the other combinations, but in QPM there was no difference between the plots with leguminous residues. In 2015, there were no differences between treatments in any cultivar. The grain yield in 2014 also was higher in LA than in all 
treatments for two cultivars, but all combinations of leguminous residues increased the grain yield. In 2015, there were no superior results for any particular treatments, but in hybrid cultivars, the LG and GC treatments were superior to the others, except for LA. In QPM, grain yield in LG was also superior for all others except for GA (Table 2).

Table 2. Performance of the two maize cultivars in 2014 and 2015 for grain yield, grain weight and dry matter

\begin{tabular}{|c|c|c|c|c|c|c|}
\hline \multirow{2}{*}{ Treatments } & \multicolumn{2}{|c|}{ Dry Matter $\left(\mathrm{Mg} \mathrm{ha}^{-1}\right)$} & \multicolumn{2}{|c|}{ Grain Yield $\left(\mathrm{Mg} \mathrm{ha}^{-1}\right)$} & \multicolumn{2}{|c|}{1,000 -grain weight $(\mathrm{g})$} \\
\hline & 2014 & 2015 & 2014 & 2015 & 2014 & 2015 \\
\hline \multicolumn{7}{|l|}{$Q P M$} \\
\hline $\mathrm{LC}$ & $46.89 \mathrm{c}$ & $80.50 \mathrm{ab}$ & $27.83 \mathrm{c}$ & $40.49 \mathrm{bc}$ & $231.60 \mathrm{a}$ & $244.58 \mathrm{a}$ \\
\hline LA & $53.37 \mathrm{a}$ & $78.92 \mathrm{~b}$ & $32.26 \mathrm{a}$ & $40.76 \mathrm{bc}$ & $244.33 \mathrm{a}$ & $265.15 \mathrm{a}$ \\
\hline LG & $50.18 \mathrm{~b}$ & $84.32 \mathrm{a}$ & $30.04 \mathrm{~b}$ & $44.34 \mathrm{a}$ & $227.13 \mathrm{a}$ & $258.10 \mathrm{a}$ \\
\hline GA & $46.32 \mathrm{c}$ & $81.04 \mathrm{ab}$ & $29.74 \mathrm{~b}$ & $43.07 \mathrm{ab}$ & $235.03 \mathrm{a}$ & $256.13 \mathrm{a}$ \\
\hline $\mathrm{GC}$ & $44.64 \mathrm{~d}$ & $78.29 \mathrm{~b}$ & $28.29 \mathrm{c}$ & $39.12 \mathrm{c}$ & $235.43 \mathrm{a}$ & $244.98 \mathrm{a}$ \\
\hline $\mathrm{C}$ & $41.05 \mathrm{e}$ & $61.52 \mathrm{c}$ & $26.23 \mathrm{~d}$ & $29.86 \mathrm{~d}$ & $176.00 \mathrm{~b}$ & $250.25 \mathrm{a}$ \\
\hline \multicolumn{7}{|l|}{ Hybrid } \\
\hline $\mathrm{LC}$ & $50.30 \mathrm{c}$ & $106.26 \mathrm{bc}$ & $29.25 \mathrm{c}$ & $54.95 \mathrm{bc}$ & $243.40 \mathrm{c}$ & $273.10 \mathrm{a}$ \\
\hline LA & $60.92 \mathrm{a}$ & $102.28 \mathrm{c}$ & $35.26 \mathrm{a}$ & $59.24 \mathrm{ab}$ & $289.65 \mathrm{a}$ & $271.70 \mathrm{a}$ \\
\hline LG & $46.78 \mathrm{~d}$ & $112.56 \mathrm{a}$ & $26.29 \mathrm{~d}$ & $62.24 \mathrm{a}$ & $250.00 \mathrm{c}$ & $281.43 \mathrm{a}$ \\
\hline GA & $49.84 \mathrm{c}$ & $104.02 \mathrm{bc}$ & $31.49 \mathrm{~b}$ & $51.83 \mathrm{c}$ & $252.48 \mathrm{c}$ & $273.05 \mathrm{a}$ \\
\hline GC & $52.32 \mathrm{~b}$ & $118.64 \mathrm{a}$ & $32.67 \mathrm{~b}$ & $63.68 \mathrm{a}$ & $271.90 \mathrm{~b}$ & $282.48 \mathrm{a}$ \\
\hline $\mathrm{C}$ & $38.35 \mathrm{e}$ & $77.44 \mathrm{~d}$ & $24.15 \mathrm{e}$ & $40.41 \mathrm{~d}$ & $173.05 \mathrm{~d}$ & $250.95 \mathrm{a}$ \\
\hline
\end{tabular}

Note. Different letters in the same column indicate significant differences by Duncan's test $(P<0.05)$. LC $=$ Leucaena and Clitoria; LA = Leucaena and Acacia; LG = Leucaena and Gliricidia; GA = Gliricidia and Acacia; GC $=$ Gliricidia and Clitoria; $\mathrm{C}=$ control.

In 2014, combinations with gliricidia were superior to protein production in the QPM cultivar (Figure 4a). The same occurred in 2015 , but in this year the LC treatment also produced protein equal to the treatments with gliricidia. In the hybrid cultivars, the GC treatment was superior for two years, except for LA and LG in 2015 (Figure 4b).

a)

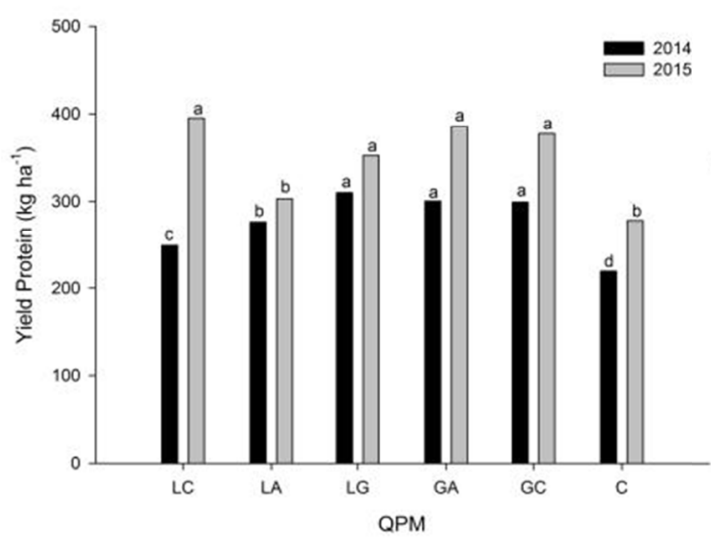



Figure 4. Protein yield in experimental treatments

Note. $\mathrm{LC}=$ Leucaena and Clitoria; LA = Leucaena and Acacia; $\mathrm{LG}=$ Leucaena and Gliricidia; GA = Gliricidia and Acacia; $\mathrm{GC}=$ Gliricidia and Clitoria; $\mathrm{C}=$ control. In a) QPM and b) Hybrid. Different letters above the bars show differences between treatments at the two cultivars at $\mathrm{P} \leq 0.05$ by Duncan's test. 


\section{Discussion}

The differences in accumulation of $\mathrm{N}$ until the pre-tasseling stage as well as in $\mathrm{N}$ remobilization in 2014 showed the influence of the treatments with lower residue quality (GA, GC), on $\mathrm{N}$ uptake in this year with eight water stress days. In addition, differences between these treatments and the control were also substantial in this year. Uptake of $\mathrm{N}$ by plants is highly dependent on root development and in cohesive soil enhancement in root growth may be associated with reduction of evaporative losses, conserved soil moisture and delayed cohesion, which can be better provided by mulching with greater preservation on soil surfaces (Cook, Valdez, \& Lee, 2006). On the other hand, soil rootability also can be enhanced by residual content of the organic matter label fraction derived from the application in previous years of biomass of low quality (Aguiar et al., 2009). In turn, the greater fast $\mathrm{N}$ releasing capacity, in treatments with residue of the highest quality, as in the LG treatment, was not able to provide better conditions for $\mathrm{N}$ uptake due to the low ability of this combination to maintain soil cover from 30 days of application (Aguiar et al., 2010). Therefore the lowest contributions in use of applied $\mathrm{N}$ were given by the treatments with higher residue quality such as LC and LG.

However, the highest $\mathrm{N}$ remobilization in plants under the GA and GC treatments did not result in increased dry matter grain weight in the first year. Remobilization is needed to route nitrogen during the grain-filling period when nitrogen uptake is generally insufficient for the high demand of the seeds (Garnett, Conn, \& Kaiser, 2009). Therefore, remobilization of $\mathrm{N}$ becomes particularly important for grain growth under conditions of abiotic stress, such as $\mathrm{N}$ deficiency when $\mathrm{N}$ depletion, especially in the leaves, tends to accelerate leaf senescence, reducing photosynthesis too rapidly compared with the duration of grain filling (Borrell, Hammer, Oosterom, \& Van, 2001). In contrast, if $\mathrm{N}$ uptake is maintained during grain filling, less $\mathrm{N}$ will be mobilized from the vegetative organs. This process may result in delayed leaf senescence, prolonged dry-matter accumulation and higher grain yield (Rajcan \& Tollenaar, 1999). On the other hand, in tropical conditions, due to the high atmospheric evaporative demand, the actual transpiration rate may be less than the potential transpiration rate even with high soil water potential, which can lead to a loss of turgidity, decreased carbon uptake, and crop growth. Therefore, in LA treatment, a more balanced ratio pre/post tasseling $\mathrm{N}$ accumulation combined with higher capacity to maintain the soil covered results in higher dry matter, seed weight and maize yield. A positive effect of leucaena residue combined with acacia was reported by Moura, Oliveira, Coutinho, Pinheiro, and Aguiar (2012) which was attributed to improvement in soil physical conditions, root growth, coupled with a higher release of $\mathrm{N}$ and $\mathrm{K}$.

In the second year, when the number of water stress days was lower than in the first year, the differences in $\mathrm{N}$ accumulation and remobilization were less clear. However, the highest maize yield of LG treatment showed that in these circumstances the use of residues of high quality with fast release of $\mathrm{N}$ may be more efficient in increasing maize yield than in combination with soil covered by residues with slower releasing of $\mathrm{N}$.

Differences in yield and protein content between treatments in this experiment showed that soil management may increase the quantity and quality of grain maize, however the influence of residues in grain protein content was also different in two years. In 2014, the protein content was higher in treatments with gliricidia for the two cultivars, due to the greater amount of $\mathrm{N}$ remobilized. In 2015 the treatments with clitoria showed the highest protein contents in the QPM cultivar. According to Silva et al. (2016) a combination of residues using clitoria, a native species, can neutralize antagonistic interactions between trees and crops and increase maize protein compared to a combination of GA, LA and LG, all exotic species. Therefore the key to obtaining the best results in agroforestry is to minimize negative interactions and maximize positive interactions in trees and crops (Thevathasan \& Gordon, 2004).

The combined grain protein content with grain yield resulted in much higher protein produced by the QPM cultivar treated with residues of gliricidia, compared to the maize treated with urea alone. Seebauer et al. (2010) showed that the grain yield and grain protein content increased simultaneously as the $\mathrm{N}$ application rate went from deficient to sufficient. In addition, the results of these authors demonstrate that the grain protein concentration of an ultra-high-protein hybrid responded linearly to increasing $\mathrm{N}$ supply, whereas the protein concentration in the low-protein hybrids was not influenced by the $\mathrm{N}$ supply. Furthermore, our results show that, in years with less water stress, different residue quality did not influence the content of protein in hybrid cultivars, compared to bare soil, probably due to dilution effect in treatments with higher yield.

\section{Conclusion}

The results presented in this study showed that combining leguminous residues applied on soil surfaces might increase the uptake of nitrogen, protein contents of maize, and grain yield. However, the effect of the residues of different qualities on the maize varies from year to year probably due to differences in its potential to release $\mathrm{N}$ or capacity to maintain soil water availability. It is worth highlighting that in this experiment, the hybrid cultivar 
was not superior to QPM regarding the amount of protein yield, which gives QPM a great advantage regarding costs to produce essential aminoacids. Our results also showed that in bare soil prone to cohesion the use of $\mathrm{N}$ in uncovered soil is not feasible for both maize yield and for protein yield compared to any of the combination of residues used.

\section{References}

Aguiar, A. C. F., Amorim, A. P., Coêlho, K. P., \& Moura, E. G. (2009). Environmental and agricultural benefits of a management system designed for sandy loam soils of the humid tropics. Revista Brasileira Ciência do Solo, 33, 1473-1480. https://doi.org/10.1590/S0100-06832009000500037

Aguiar, A. C. F., Bicudo, S. J., Costa Sobrinho, J. R. S., Martins, A. L. S., Coelho, K. P. O., \& Moura, E. G. (2010). Nutrient recycling and physical indicators of an alley cropping system in a sandy loam soil in the Pre-Amazon Region of Brazil. Nutrient Cycling in Agroecosystems, 86, 189-198. https://oi.org/10.1007/ s10705-009-9283-6

Association of Official Analytical Chemists (AOAC). (2005). Official Methods of Analysis (16th ed.). AOAC International, Washington, DC.

Bello, O. B., Olawuyi, O. J., Ige, S. A., Mahamood, J., Afolabi, M. S., Azeez, M. A., \& Abdulmaliq, S. Y. (2014). Agro-nutritional variations of Quality Protein Maize (Zea mays L.) in Nigeria. Journal Agricultural Sciences, 59, 101-116. https://doi.org/10.2298/jas1402101b

Benjamin, J. G., Nielsen, D. C., \& Vigil, M. F. (2003). Quantifying effects of soil conditions on plant growth and crop production. Geoderma, 116, 137-148. https://doi.org/10.1016/S0016-7061(03)00098-3

Borrell, A. K., Hammer, G. L., \& Oosterom, Van. E. (2001). Stay-green: a consequence of the balance between supply and demand for nitrogen during grain filling? Annals of Applied Biology, 138, 91-95. https://doi.org/ 10.1111/j.1744-7348.2001.tb00088.x

Cook, R. J., Valdez, G. S. B., \& Lee, H. C. (2006). Mulch effects on rainfall interception, soil physical characteristics and temperature under Zea mays L. Soil and Tillage Research, 91, 227-235. https://doi.org/ 10.1016/j.still.2005.12.007

Daniells, I. G. (2012). Hardsetting soils: A review. Soil Research, 50, 349-359. https://doi.org/10.1071/SR11102

Denmead, O. T., \& Shaw, R. H. (1960). Availability of soil water to plants as affected by soil moisture content and meteorological conditions. Agronomy Journal, 43, 385-390.

Gaju, O., Allard, V., Martre, P., Le Gouis, J., Moreau, D., Bogard, M., .. Foulkes, M. J. (2013). Nitrogen partitioning and remobilization in relation to leaf senescence, grain yield and grain nitrogen concentration in wheat cultivars. Field Crops Research, 155, 213-223. https://doi.org/10.1016/j.fcr.2013.09.003

Garnett, T., Conn, V., \& Kaiser, B. N. (2009). Root based approaches to improving nitrogen use efficiency in plants. Plant Cell Environment, 32, 1272-1283. https://doi.org/10.1111/j.1365-3040.2009.02011.x

Hochman, Z., Carberry, P. S., Robertson, M. J., Gaydon, D. S., Bell, L. W., \& McIntosh, P. C. (2011). Prospects for ecological intensification of Australian agriculture. European Journal of Agronomy, 44, 109-123. https://doi.org/10.1016/j.eja.2011.11.003

Mbuya, K., Nkongolo, K. K., \& Kalonji, M. (2011). Nutritional analysis of quality protein maize varieties characteristics in a breeding program. International Journal of Plant Breeding and Genetics, 5, 317-327. https://doi.org/10.3923/ijpbg.2011.317.327

Mon, J., Bronson, K. F., Hunsaker, D. J., Thorp, K. R., White, J. W., \& French, A. N. (2016). Interactive effects of nitrogen fertilization and irrigation on grainyield, canopy temperature, and nitrogen use efficiency in overhead sprinkler-irrigated durum wheat. Field Crops Research, 191, 54-65. https://doi.org/10.1016/ j.fcr.2016.02.011

Moura, E. G., Moura, N. G., Marques, E. S., Pinheiro, K. M., Costa Sobrinho, J. R. S., \& Aguiar, A. C. F. (2009). Evaluating chemical and physical quality indicators for a structurally fragile tropical soil. Soil Use and Management, 25, 368-375. https://doi.org/10.1111/j.1475-2743.2009.00238.x

Moura, E. G., Oliveira, A. K. C., Coutinho, G., Pinheiro, K. M., \& Aguiar, A. C. F. (2012). Management of a cohesive tropical soil to enhance rootability and increase the efficiency of nitrogen and potassium use. Soil Use and Management, 28, 370-377. https://doi.org/10.1111/j.1475-2743.2012.00424.x 
Moura, E. G., Sena, V. G. L., Sousa, C. C. M., Silva, F. R., Coelho, M. J. A., Macedo, V. R. A., \& Aguiar, A. C. F. (2016). Enhancement of the rootability of a structurally fragile tropical soil using gypsum and leguminous residues to increase the yield of maize. Soil Use and Management, 32, 118-126. https://doi.org/10.1111/ sum. 12251

Moura, E. G., Serpa, S. S., Santos, J. G. D., Costa Sobrinho, J. R. S., \& Aguiar, A. C. F. (2010). Nutrient use efficiency in alley cropping systems in the Amazonian periphery. Plant and Soil, 335, 363-371. https://doi.org/10.1007/s11104-010-0424-0

Mulumba, L. N., \& Lal, R. (2008). Mulching effects on selected soil physical properties. Soil and Tillage Research, 98, 106-111. https://doi.org/10.1016/j.still.2007.10.011

Ngaboyisonga, C., Njoroge, K., Kirubi, D., \& Githiri, S. M. (2012). Quality protein maize under low N and drought environments: Endosperm modification, protein and tryptophan concentrations in grains. Agri Journal, 7, 327-338.

Prasanna, B. M., Vasal, S. K., Kassahun, B., \& Singh, N. N. (2001). Quality protein maize: A review. Current Science, 81, 1308-1319. Retrieved from http://repository.cimmyt.org:8080/xmlui/bitstream/handle/10883/ 1968/75947.pdf

Qamar, R., Ehsanullah, Saqib, M., Muhammad, R. J. H., Rehman, A., Atiqueur, R., \& Ali, A. (2015). Influence of Tillage and Mulch on Soil Physical Properties and Wheat Yield in Rice-Wheat System. West African Journal of Applied Ecology, 23, 21-38. Retrieved from http://www.ajol.info/index.php/wajae/ article/view/121891/111366

Rajcan, I., \& Tollenaar, M. (1999). Sink ratio and leaf senescence in maize: I. Dry matter accumulation and partitioning during grain filling. Field Crops Research, 60, 245-253. https://doi.org/10.1016/S0378-4290 (98)00142-7

Seebauer, J. R., Singletary, G. W., Krumpelman, P. M., Ruffo, M. L., \& Below, F. E. (2010). Relationship of source and sink in determining kernel composition of maize. Journal of Experimental Botany, 61, 51-519. https://doi.org/10.1093/jxb/erp324

Silva, A. G. M., Aguiar, A. C. F., Moura, E. G., \& Jorge, N. (2016). Influence of soil cover and N and K fertilization on the quality of biofortified QPM in the humid tropics. Journal of the Science of Food and Agriculture, 96, 3807-3812. https://doi.org/10.1002/jsfa.7574

Thevathasan, N. V., \& Gordon, A. M. (2004). Ecology of tree intercropping system in the North temperature region: Experiences from southern Ontario, Canada. Agroforest Syst., 61, 257-268. https://doi.org/10.1007/ 978-94-017-2424-1 18

Tian, G., Brussaard, L., \& Kang, B. (1995). An index for assessing the quality of plant residues and evaluating their effects on soil and crop in the (sub-) humid tropics. Appl Soil Ecology, 2, 25-32. https://doi.org/10.1016/0929-1393(94)00033-4

Ufaz, S., \& Galili, G. (2008). Improving the Content of Essential Amino Acids in Crop Plants: Goals and Opportunities. Plant Physiology, 147, 954-961. https://doi.org/10.1104/pp.108.118091

Wang, H., Guo, Z., Shi, Y., Zhang, Y., \& Yu, Z. (2015). Impact of tillage practices on nitrogen accumulation and translocation in wheat and soil nitrate-nitrogen leaching in drylands. Soil Tillage Research, 153, 20-27. https://doi.org/10.1016/j.still.2015.03.006

\section{Copyrights}

Copyright for this article is retained by the author(s), with first publication rights granted to the journal.

This is an open-access article distributed under the terms and conditions of the Creative Commons Attribution license (http://creativecommons.org/licenses/by/4.0/). 